УДК 159.923:331.54:659.1

DOI https://doi.org/10.26661/2310-4368/2020-3-12

\title{
ВПЛИВ СОЦІАЛЬНОЇ РЕКЛАМИ ТА ЛІДЕРСЬКИХ ЯКОСТЕЙ ОСОБИСТОСТІ НА ЇЇ ПРОФЕСІЙНЕ САМОВИЗНАЧЕННЯ
}

\author{
Нежинська О. О. \\ кандидат психологічних наук, дочент, \\ доиент кафедри психології \\ Інститут підготовки кадрів державної служби зайнятості України \\ вул. Нововокзальна, 17, Київ, Украӥна \\ orcid.org/0000-0002-0800-356X \\ helena.nezhynska@gmail.com
}

\begin{abstract}
Ключові слова: сочіальна реклама, лідер, лідерські якості, лідерський потенціал, профоріснтаиія особистості, професійне самовизначення.
\end{abstract}

У статті висвітлено особливості впливу соціальної реклами та лідерських якостей особистості на іi професійне самовизначення. Виявлено, що сучасні різноманітні трансформації у суспільстві, а також сьогоднішні проблеми пандемії коронавірусної хвороби призвели до істотних негативних змін на ринку праці, зокрема й появи значних масштабів безробіття, соціальної незахищеності тощо, тому сьогодні вельми актуальним $є$ пошук шляхів розв'язання окреслених проблем, покращення нинішньої ситуації, пришвидшення залучення спеціалістів до трудової діяльності тощо. Поінформовано, що проблему професійного самовизначення особистості розглядали багато відомих вітчизняних $\mathrm{i}$ зарубіжних дослідників. Виділено види домінантних мотивів особистості під час реалістичного вибору професії, що може бути допомогою під час діагностики в процесі профорієнтаційної роботи.

Визначено психологічні особливості соціальної реклами, зокрема і вплив соціальної реклами на сприйняття особистості, тривалість процесу уваги завдяки відповідним засобам, які використовуються в рекламі. Виявлено вплив соціальної реклами на суспільство та молодь. Зафіксовано, що під час професійного самовизначення важливо розкрити власні лідерські задатки й якості, лідерський потенціал та лідерські цінності, оскільки мобілізація внутрішніх резервів допоможе особистості у повсякденній поведінці, міжособистісній комунікації, а також сприятиме збагаченню власної діяльності новими способами іiі виконання та підвищить особистісну ефективність загалом. Зазначено, що невміння правильно користуватися власними ресурсами, виявляти та розкривати їх можуть викликати в особистості проблеми психологічного характеру в умовах професійногосамовизначення. Підкреслено,щооднієюзумовправильного вибору професії є профорієнтація. Констатовано, що для професійного самовизначення громадян у державі здійснюється професійна орієнтація шляхом професійного інформування, професійного консультування та професійного відбору завдяки діяльності Державної служби зайнятості. 


\title{
THE INFLUENCE OF SOCIAL ADVERTISING AND PERSONAL LEADERSHIP QUALITIES ON PROFESSIONAL IDENTITY
}

\author{
Nezhynska O. O. \\ Candidate of Psychological Sciences, Associate Professor, \\ Senior Lecturer at the Department of Psychology \\ Ukrainian State Employment Service Training Institute \\ Novovokzalna str., 17, Kyiv, Ukraine, \\ orcid.org/0000-0002-0800-356X \\ helena.nezhynska@gmail.com
}

\begin{abstract}
Key words: social advertising, leader, leadership qualities, leadership potential, career guidance of person, professional identification.
\end{abstract}

The article covers special aspects of the influence of social advertising and personal leadership qualities on professional identity. It is established that a range of modern social transformations and current problems caused by the COVID-19 pandemic led to significant adverse changes in the labor market, including the large scale of unemployment etc. Thus, it seems expedient today to find ways of dealing with the above problems, improving the unfolding situation, activating the involvement of experts in labor activities etc. The author marks that many prominent foreign and domestic scientists have studied the issue of professional identity of personality. Types of predominant personal motives during the real choice of a profession, which can favor when conducting diagnostics in the context of career guidance activities, have been marked.

The paper determines the psychological features of social advertising, particularly its influence on the person's perception, the duration of attraction due to the relevant means used in advertisement etc. It is mentioned the effect of social advertising on society and the youth. The author emphasizes that under professional identification, it is essential to realize the personal leadership makings and qualities, leadership values and leadership potential because the mobilization of internal resources assists an individual in terms of daily behavior, interpersonal communication; therefore, it will contribute to the enrichment of one's activity with new ways of its execution and advance personal effectiveness. The research points out that a lack of skill to put one's resources to good use, identify and disclose them can cause psychological problems of a person in the context of professional identity. It is established that career guidance is one of the conditions of the right choice of a profession. The author confirms that the state maintains career guidance through professional informing, professional counseling and professional selection driven by the State Employment Service for professional identification of citizens.
Постановка проблеми. Сьогодні від держави існує запит на вільну та суспільно активну особистість, яка володіс лідерськими якостями й усвідомлено та відповідально здійснює вибір власного життєвого шляху. Загальновідомо, що професійне самовизначення особистості здійснюється у шкільному віці, коли важливим моментом у житті молодої людини $є$ вибір нею майбутньої професії. При цьому паралельно із позитивним настроєм, мотивацією, вподобаннями й інтересами, планами і поглядами під час вибору майбутньої професії може бути присутній і негативізм, відчуженість у межах реакції емансипації від дорослих, що виявляються у відносинах із батьками, педагогами, значущими особистостями тощо. Водночас сьогодні в умовах інституційних перетворень на ринку праці часто вже доросла людина опиняється без роботи. Однією з умов ефективного та результативного продовження нею професійного шляху $\epsilon$ швидке реагування, розгляд різних варіантів $\mathrm{i}$ пропозицій у процесі пошуку нової вакансії, професійне самовизначення. Зрозуміло, важливим $\epsilon$ власний попередній професійний досвід, набуті компетентності та якості, але також потрібно брати до уваги і бачення нових векторів та напрямів у процесі прийняття рішення щодо подаль- 
шої професійній діяльності. Очевидно, не завжди це легко зробити, оскільки людина опиняється у складній (а для когось і стресовій) ситуації, не може знайти відповідей на прості запитання, опанувати себе, прийняти конструктивне рішення, не бачить подальших кроків на професійному шляху. У такому разі існує серйозна загроза як зниження та втрати мотивації до пошуку роботи, так і зниження самооцінки загалом, виникнення почуття невпевненості у собі, тривожності, особистої незахищеності, підвищення емоційного навантаження, що може призвести до нервових розладів, розвитку депресивних станів, апатії і негативно позначитися на здоров'ї загалом. Тут важливу роль підтримки та пошуку виходу із такої ситуації для особистості, з одного боку, відіграють іiі оточення, інформація, зокрема й соціальна реклама, а з іншого - уподобання та власне особистісні якості особистості, зокрема й лідерські. Отож, окрім зовнішніх чинників, які впливають на професійне самовизначення особистості, існують і внутрішні.

Аналіз останніх досліджень і публікацій із проблеми професійного самовизначення особистості свідчить про те, що у вітчизняній психології та педагогіці це питання почало активно досліджуватися 3 70-х років XX ст., при цьому воно вивчалося у контексті проблем розвитку особистості (С.А. Климов [19], М.Ю. Пряжніков [18] та ін.), а також впливу мотиваційно-ціннісної сфери особистості на вибір професії, формування життєвих перспектив особистості та плануванням майбутнього, соціального самовизначення особистості, проблеми «Я-концепції» як фактора професійного самовизначення особистості тощо. Водночас у зарубіжних дослідників проблема професійного самовизначення розглядалася через призму концепту «професійна кар'єра», що відображено у працях Дж. Холланда [21] та ін. Відповідні дослідження доводять, що професійне самовизначення є складним процесом, який є невід'ємним від цілісного розвитку особистості в цілому.

Професійний вибір є одночасно самовизначенням життєвого професійного сценарію, під час якого особистість виявляє життєвий сенс і призначення професії, з'ясовує, які базові цінності та спрямування в ній можна реалізувати, а також те, як сприймають цей вибір інші, планує, які існують можливості досягнення цілей, реалізації потреб та задоволення життям у цілому. Звідси випливає, що актуальність цього питання не викликає сумніву, що і зумовило вибір теми цього дослідження.

Мета статті - висвітлити вплив соціальної реклами та лідерських якостей особистості на іiі професійне самовизначення.

Виклад основного матеріалу дослідження. Підготовка молодих людей до трудової діяльно- сті має відбуватися за рахунок не лише освітніх закладів, у яких вони здобували освіту, а й за допомогою налагодження системи працевлаштування молоді. На всіх етапах педагогічного процесу навчання має спрямовуватися на формування компетентної особистості з урахуванням іiі особистісних якостей, зокрема й лідерських, яка поєднує теоретичні та практичні знання й уміння на основі усвідомленого професійного самовизначення. Але не всі учні та абітурієнти, що вступають сьогодні до вищих навчальних закладів, мають чітку професійну спрямованість. Однією 3 причин часто $є$ недостатня готовність освітян до здійснення профорієнтаційної роботи відповідно до вимог сьогодення, зокрема й виявлення педагогами лідерських задатків та якостей молодої людини і допомога у її спрямуванні у відповідному напрямі [17]. Слід посилити увагу і щодо соціальної реклами, яка $є$ вагомим інструментом у посиленні мотивації молодої людини, яка перебуває на роздоріжжі, стоїть перед вибором шляху до професійної діяльності [8-10].

Це стосується і тієї категорії людей, які з різних причин опинилися без роботи. Необхідно зазначити, що сучасні різноманітні трансформації у суспільстві, зокрема й у сфері економіки та соціальної політики, а також сьогоднішні проблеми пандемії коронавірусної хвороби призвели до істотних негативних змін на ринку праці, зокрема й появи значних масштабів безробіття, соціальної незахищеності від ринкових ризиків окремих категорій населення, зокрема й молоді, послаблення державного регулювання працевлаштування, скорочення робочих місць, брак дієвих програм соціального захисту тощо. Так, виникає не лише проблема вимушеної незайнятості, але й загроза руйнування трудового потенціалу, відчуження молоді від інтересів суспільного виробництва та від процесів суспільного відтворення загалом. Тому сьогодні актуальним $€$ пошук шляхів розв'язання проблем, пов'язаних із покращенням нинішньої ситуації, пришвидшення залучення спеціалістів, зокрема і молодих, до трудової діяльності. У широкому розумінні поняття «працевлаштування» - це процес будь-якого влаштування на роботу, зокрема й самостійного, а також за допомогою служби зайнятості [1].

Слід зазначити, що проблему професійного самовизначення особистості розглядали багато відомих вітчизняних і зарубіжних дослідників. Так, Е. Берн виділяв життєві сценарії та життєві стратегії. До перших він зараховував «програми поступального розвитку, які були сформовані в ранньому дитинстві під впливом батьків, які детермінують поведінку індивіда в важливих аспектах його життя» і які охоплюють все життя людини; до других - загальні уявлення про людське життя [5]. 
Сценарії та стратегії реалізуються в професійній сфері у вигляді «професійної долі», професійного та кар'єрного розвитку тощо. А. Адлер виділяє стиль життя - унікальне поєднання рис, способів поведінки і звичок, сукупність яких визначає неповторну картину існування індивідуума, що визначається у 4-5-річному віці, зберігається все життя і не піддається тотальним змінам, стаючи головним стрижнем поведінки [3]. Поняття «потенційне стосовно розвитку особистості» співвідноситься з ії здібностями і задатками, що відображено у гуманістичних теоріях особистості (А. Маслоу, К. Роджерс, В. Франкл, Е. Фром) і тісно пов'язане з терміном «актуалізація», який трактується як перехід знань, умінь, навичок, різних форм поведінки, емоційних станів із потенційного стану в актуальний. У концепції самоактуалізації А. Маслоу професійне самовизначення розглядається як частина професійного розвитку через прагнення людини до вдосконалення, peaлізації та вираження себе в значущих сферах життєдіяльності. На його думку, основним $є$ усвідомлене активне опанування особистістю свого внутрішнього світу та пізнання особливостей соціально-психологічних процесів та явищ, що безпосередньо впливають на якість життя [11].

Залежно від характеру домінантних мотивів розрізняють декілька рівнів реалістичного вибору професії [17]:

- економічний, для якого характерним є прагнення до високого заробітку в разі вираженого ігнорування інших характеристик професій;

- соціальний, що визначається домінантною спрямованістю на отримання престижної професії;

- духовний, провідним мотивом якого є прагнення до самовдосконалення, розкриття творчого потенціалу.

Так, у процесі професійного самовизначення (нарівні з іншими) соціальна реклама може відіграти одну зі значущих ролей в інформуванні особистості. За допомогою рекламної комунікації можливо знаходити відповіді на власні найактуальніші питання, а також отримувати контактні дані організацій, що можуть бути корисними під час підбору вакансій відповідно до власних схильностей та вподобань. Соціальна реклама $\epsilon$ одним із найбільших каналів подання потрібного знання та правильної координації дій у контексті володіння інформацією, зокрема й нормативної бази, що дає змогу краще орієнтуватися на ринку трудових відносин під час професійного самовизначення.

Соціальна реклама $є$ об'єктом дослідження як зарубіжних, так і вітчизняних науковців. Цій темі присвячено роботи Т. Булах [8], А. Досенко [9], П. Кузнецова [10] та ін. Термін «соціальна реклама» $\epsilon$ перекладом 3 англійської поняття «public advertising», а у законодавстві України соціальна реклама інтерпретується як «інформація будь-якого виду, розповсюджена в будь-якій формі, яка спрямована на досягнення суспільно корисних цілей, популяризацію загальнолюдських цінностей і розповсюдження якої не має на меті отримання прибутку» [2]. Місія соціальної реклами - це зміна ставлення людей до проблем суспільства, а в довгостроковій перспективі пропозиція нових соціальних цінностей, затребуваних суспільством.

Необхідно зазначити, що психологічні особливості соціальної реклами безпосередньо впливають на суспільство, особливо на молодь, на формування нового покоління та засвоєння відповідних норм та цінностей загалом. У цьому потужність її впливу варіюється залежно від соціального статусу особистості. Поглиблена й стійка зосередженість уваги глядача, іï інтенсивність на рекламному повідомленні - умови ефективності соціальної реклами. Водночас установлено, що найбільші витрати нервової системи, іiї енергії відбуваються тоді, коли рекламне повідомлення походить від авторитетної особи. Загалом, сприйняття соціальної реклами - складний процес, особливість якого полягає в цілісності, адже реклама $\epsilon$ комплексним подразником і сприймається свідомістю як єдине ціле. Сьогодні реклама здатна формувати не тільки потреби, а й виховувати, навіювати соціальні стереотипи, оскільки це один зі складників соціалізації сучасної молоді разом із традиційними інститутами соціалізації (сім'єю, групами однолітків, школою) [20].

Важливим чинником у процесі привертання уваги соціальної рекламою є відповідність, а іiі подразники адресовані внутрішньому стану й потребам особи, якій адресовано повідомлення. Сприйняття відбирає з рекламного повідомлення лише найбільш необхідне для життєдіяльності особистості, а також, відповідно, вона уникає тієї інформації, яка збігається чи суперечить іiі переконанням. Ефективність впливу соціальної реклами значно залежить від тривалості процесу уваги, викликаного подразником. Подразник, який діє тривалий час (наприклад музика, яка лунає протягом усього рекламного фільму), дуже швидко стомлює. Має свою значення під час сприйняття реклами і іiі обсяг (як-от величезний рекламний щит може служити гарним подразником за умови, що поруч немає інших реклам або будь-якої інформації). Істотним чинником спонукання уваги є ступінь новизни порушуваної проблеми. Кожен рекламний засіб посилення уваги об'єкта проведення соціальної рекламної кампанії має повідомляти щось нове, доповнювати деякі дані новими. Для звернення 
уваги на соціальну рекламу використовується прийом проблемної ситуації, якою є проблема професійного самовизначення. Така позиція спонукає до роздумів, викликаючи потребу в заглибленні в сутність проблеми. Це може бути, наприклад, підтримка незахищених верств населення (молоді, безробітних), популяризація діяльності громадських організацій та фондів, просування ідеї здорового способу життя серед населення, тематика харчування, покращення життя тощо.

Наявність лідерських якостей, їх розкриття та прояв у процесі життєдіяльності особистості, а також під час здійснення нею професійного шляху $\epsilon$ одними з ключових моментів у розвитку особистості загалом. Як зазначають Х. Оуен, В. Ходжсон, Н. Газзар [16], «лідерство починається з того, що людина знаходить у собі сміливість стати тим, ким вона здатна стати. Лідерство передбачає безперервне навчання впродовж усього життя. Завдяки навчанню ми пізнаємо себе, навколишній світ і реальні проблеми навколо нас. До навчання слід ставитися як до процесу власного перетворення»». Варто навести висновки дослідників щодо питання лідерства $[4 ; 7 ; 15-16]$, де вони підкреслюють, що лідер (від англ. leader - особа, яка веде за собою) - це авторитетний член групи, якому вона надає право приймати найвідповідальніші рішення, що стосуються інтересів усієї групи. Лідер значно залежить від групи, яка вимагає вираження та транслювання інтересів групи. Лише за цієї умови послідовники не просто йдуть за своїм лідером, а й хочуть іти за ним.

Термін «лідерство» (відповідно до Оксфордського словника) з'явився приблизно 1300 р. тому. Ще за часи античності провідні мислителі, серед яких і Платон, намагалися виділити характерні риси, завдяки яким особистість могла б стати видатною історичною постаттю. Свої думки щодо сутності лідерських якостей пізніше висловлювали А. Адлер, М. Вудкок, Г. Форд, 3. Фройд, К. Юнг та інші відомі науковці-дослідники.

М. Бауер [4] (відомий теоретик і практик 3 питань управління та лідерства) пропонує відмовитися від застарілої системи керівництва, яка побудована на авторитарності, жорсткій ієрархії та вертикальному підпорядкуванні, замінивши ii на спільноту лідерів і лідерських команд, де панує вміння слухати своїх працівників і чути їх. Лише така організаційна структура здатна розвинути у співробітниках найкращі якості, бажання працювати й креативно мислити.

Але тут слід зазначити, що саме на етапі професійного самовизначення потрібно вміти розкрити свої лідерські задатки й якості, лідерський потенціал та цінності, а також виявляти або ж виявити їх, що може слугувати саме тим потуж- ним поштовхом і виходом із проблемної ситуації. Це можуть стати впевненість і сила, сфокусованість і спокій, харизма й енергійність, позитив i наполегливість, щедрість і відкритість, активність і ерудиція, стресостійкість і вмотивованість, щирість і зацікавленість, компетентність і досвід тощо. Це важливі та провідні риси у структурі особистості, про які потрібно пам'ятати та на яких варто наголосити саме під час професійного самовизначення, оскільки саме вони можуть у такий момент зіграти головну та вирішальну роль у визначенні подальших кроків у життєдіяльності особистості та вплинути на всі подальші професійні звершення та майбутні перемоги. Так, наприклад, у кризових для людини ситуаціях важливу роль безперечно відіграє саморегуляція особистості, почуття власної гідності, тобто ії внутрішній потенціал та внутрішні резерви, те, наскільки людина намагається зберегти власне обличчя та внутрішню узгодженість за рахунок значущості пріоритетів та обраних цілей, а також прагнення ïх досягти. Не менш значущим $\epsilon$, на нашу думку, відтінення постійного перегляду власних пріоритетів й цілей в умовах таких змін у професійній кар'єрі, оскільки це мотивує на пошук відповідей і рішень в умовах професійного самовизначення. Також цим $є$ вміння як прийняти проблемну ситуацію, так і відпустити іiі, а також зняти емоційну напругу і поступово збільшувати здатність йти далі, змінити ставлення до людей, ситуації тощо. Тому під час професійного самовизначення наявність лідерських якостей, їх прояв, мобілізація внутрішніх резервів допоможуть ввести це у повсякденну поведінку, міжособистісну комунікацію, коли формуються навички поведінки у критичних ситуаціях, відпрацьовуються також уміння збагачувати діяльність новими способами виконання, що підвищує іiї особистісну ефективність загалом.

Невміння правильно користуватися власними ресурсами, виявляти та розкривати їх можуть викликати в особистості проблеми психологічного характеру в умовах професійного самовизначення, а саме: невпевненість у собі, власні стереотипи та моделі стереотипної поведінки, власні обмеження та комплекси, страх подивитися масштабніше та ширше, спробувати шукати i знаходити інші варіанти та можливості, будувати нові кар'єрні траєкторії.

Не можна оминути і ще один із провідних факторів під час вибору своєї майбутньої професійної діяльності, особливо для молодої людини. Ним $\epsilon$ усвідомлення специфіки особистісної позиції у сфері гендерної поведінки. Доведено, що на формування та розвиток особистості впливають суспільство й культура, а також закріплені в них подання про зміст і специфіку гендерних ролей. 
Установлено, що гендерні стереотипи часто диктують, приписують чоловікам i жінкам певні психологічні якості, норми поведінки, рід занять, професії тощо, цементують наявні гендерні розбіжності, часто ускладнюють оптимізацію процесів у сфері гендерних відносин тощо. Їх негативна роль виявляється в гальмуванні гармонізації статеворольових позицій, очікувань і вимог, оскільки їх основою $є$ викривлення уявлення про стать і гендерні ролі, що можна спостерігати, на жаль, і дотепер у сфері соціальної реклами. Тому потрібно брати до уваги цей факт під час професійного самовизначення, намагатися заздалегідь створювати умови задля власного особистісного розвитку та самореалізації [12-14].

Далі варто підкреслити, що однією 3 умов правильного вибору професії є профорієнтація, що $є$ комплексом психолого-педагогічних і медичних заходів, спрямованих на оптимізацію процесу працевлаштування у відповідності до бажань, схильностей, здібностей та $з$ урахуванням потреби суспільства у фахівцях. Саме у процесі профорієнтації та профорієнтаційних заходів можна виявити в особистості домінантні мотиви вибору професії, про які йшлося вище. Важливо додати, що ігнорування природного фактора може призвести до того, що обрана трудова діяльність буде виконуватися зі значним напруженням, наслідком чого стануть втрата інтересу до професії, розчарування у своїх здібностях, нервові захворювання. Тому сучасний підхід у профорієнтації - особистісно-орієнтований - припускає своєчасну підтримку та розвиток тих особливостей і характеристик особистості, які є передумовою для майбутньої успішної професійної діяльності, сприяють пізнанню довкілля, самопізнанню, самореалізації особистості, усвідомленню власної ролі у виборі професії, прийняттю відповідальності за нього. При цьому також слід урахувати необхідність своєчасного виявлення та корекції рис особистості, які можуть перешкоджати професійному становленню, викликати професійну деформачію особистості - переоцінку своїх професійних підходів і цінностей, нечутливість до інших соціальним і професійним позиціям, конфліктність у відносинах з іншими, формування специфічної професійної етики, що обслуговує вузькоособисті устремління $[6 ; 18]$.

Для професійного самовизначення громадян у нашій державі професійна орієнтація здійснюється шляхом професійного інформування, професійного консультування та професійного відбору завдяки діяльності Державної служби зайнятості. Фахівці служби зайнятості та $\dddot{11}$ центрів, крім професійної допомоги, надають моральну та психологічну підтримку особам, які звертаються до центрів зайнятості, а також намагаються сприяти підвищенню мотивації безробітних осіб до працевлаштування шляхом проведення тренінгів, семінарів, участі у фестивалях і ярмарках професій тощо. Ще одним 3 інструментів є електронна система, а також різні пошукові системи або спеціальні портали приватних агенцій зайнятості, зокрема й через засоби масової інформації, соціальну рекламу тощо. Надання такої психологічної допомоги, підтримки, підготовки та перепідготовки, професійного самовизначення можна забезпечити в Інституті підготовки кадрів державної служби зайнятості, у якому активно впроваджуються інноваційні технології, метою яких $€$ забезпечення розвитку та вдосконалення важливих якостей особистості, вміння збагачувати власну діяльність новими способами виконання, розвиток професійної гнучкості, мобільності, розкриття внутрішніх ресурсів тощо. Це також навчання мистецтва, вміння керувати собою, своїм станом, підвищення особистої ефективності, конструктивні та продуктивні відносини під час взаємодії з іншими, що ефективно розповсюджуватиметься на всі сфери життя людини в процесі професійного самовизначення.

Висновки. Отже, у результаті дослідження висвітлено вплив соціальної реклами та лідерських якостей особистості на іï професійне самовизначення. Виявлено, що важливим кроком у життєвому та професійному становленні людини $\epsilon$ вибір професії як багатоетапний процес вироблення та ухвалення рішення щодо професійного самовизначення. У цьому контексті встановлено, що важливу роль при цьому відіграють зовнішні (вплив соціальної реклами) та внутрішні (наявність лідерських якостей особистості) чинники.

Зазначено, що важливим для людини є подолання психологічних проблем у процесі переосмислення, планування та побудови кар'єрної траєкторії задля досягнення нею поставлених життєвих і фахових цілей, спираючись при цьому на власні якості та характеристики. Виділено, що необхідною умовою в процесі професійного самовизначення $€$ і створення суспільством умов для самовияву та реалізації потенціалу особистості, iii самовдосконаленню, а також надання можливості людині зробити власний внесок у розвиток трудового потенціалу суспільства шляхом відповідності його сьогоднішнім потребам, що можна забезпечити в процесі навчання або підвищення кваліфікації в Інституті підготовки кадрів Державної служби зайнятості України. 


\section{ЛIТЕРАТУРА}

1. Про зайнятість населення : Закон України від 05.07.2012 р. № 5067-VI. URL: https://zakon.rada.gov.ua/ laws/show/5067-17\#Text

2. Про рекламу : Закон України від 03.07.1996 р. № 270/96-BP. URL: https://zakon.rada.gov.ua/laws/ show/270/96-вр\#Теxt

3. Адлер А. Наука жить ; пер. с англ. Киев : Port-Royal, 1997. 286 с.

4. Бауэр М. Курс на лидерство: Альтернатива иерархической системе управления компанией ; пер с англ. Москва : Альпина Паблишер, 2014. 200 с.

5. Берн Э. Игры, в которые играют люди. Люди, которые играют в игры ; пер. с англ. Москва : Эксмо, 2010. $576 \mathrm{c}$.

6. Бондарчук O.I. Модель особистісного зростання майбутніх фахівців. Тези I Всеукраїнської науково-практичної інтернет-конференції (з міжнародною участю) «Особистісне зростання: теорія і практика» (м. Житомир, 22 квітня 2016 р.). Житомир, 2016. С. 9-12.

7. Бондарчук O.І., Нежинська О.О. Лідерство у діяльності керівника освітньої організації : спецкурс для слухачів очно-дистанційної форми навчання в системі післядипломної педагогічної освіти ; НАПН України, Ун-т менедж. освіти. Київ, 2017. 38 с.

8. Булах Т.Д. Специфіка телевізійної реклами. Вісник Харківської державної академії культури. Харків, 2010. С. 167-175.

9. Досенко А.К. Соціальна реклама і механізми впливу на цільову аудиторію. URL: http://www. kymu.edu.ua/wsc/toms/09/112-114.pdf

10. Кузнецов П.А. Социальная реклама: теория и практика: учеб. пособие для студентов вузов. Москва : ЮНИТИ-Дана, 2010. 175 с.

11. Маслоу А. Мотивация и личность. 3-е изд. Серия «Мастера психологии». Санкт-Петербург и др. : Питер, 2003. 352 с.

12. Нежинська О.О. Вплив гендерних стереотипів батьків на особистісний розвиток підлітка. Актуальні проблеми психології: зб. наук. праць Інституту психології ім. Г.С. Костюка НАПН України ; за ред. С.Д. Максименка, Л.М. Карамушки. Київ, 2014. Т.I : Організаційна психологія. Економічна психологія. Соціальна психологія / за ред. С.Д. Максименка, Л.М. Карамушки. Київ, 2014. Вип. 40. C. $143-147$.

13. Нежинська О.О. Гендерна толерантність як чинник особистісного розвитку підлітків. Вісник післядипломної освіти: зб. наук. пращь Ун-ту менедж. освіти НАПН України ; редкол. : О.Л. Ануфрієва [та ін.] ; голов. ред. В.В. Олійник. Київ : АТОПОЛ, 2014. Вип. 12(25). С. 218-226.

14. Нежинська О.О., Зоріна В.І. Психологічна підготовка педагогічних працівників до розвитку морально-ціннісних уявлень підлітків: спецкурс для слухачів очно-дистанц. форми навчання в системі післядиплом. пед. освіти ; НАПН України, УН-т менедж. освіти. Київ, 2014. 44 с.

15. Нежинська О.О., Тименко В.М. Коучинг як технологія розвитку лідерства у сфері освіти. Теоретичний та науково-методичний часопис «Вища освіта Украӥни»; 2017, № 2 (додаток 1) ; Тематичний випуск «Університет і лідерство». Київ : Інститут вищої освіти НАПН України, 2017. С. 65-68.

16. Оуэн Х., Ходжсон В., Газзард Н. Призвание - лидер: Полное руководство по эффективному лидерству. Днепропетровск : Баланс Бизнес Букс, 2005. 384 с.

17. Підготовка керівників закладів освіти до профорієнтаційної роботи з учнівською та студентською молоддю: спецкурс для слухачів очно-дистанц. форми навчання в системі післядиплом. пед. освіти / О.І. Бондарчук, А.С. Москальова, О.О. Нежинська, О.А. Прокопенко ; НАПН України, Ун-т менедж. освіти. Київ, 2012. 50 с.

18. Пряжникова Е.Ю., Пряжников Н.С. Профориентация : учеб. пособие для студ. высш. учеб. заведений. Москва : Академия, 2005. 496 с.

19. Климов Е.А. Психология профессионального самоопределения : учеб. пособие. Ростов-на-Дону : Феникс, 1996. 512 с.

20. Психологія реклами : навч. посіб. для студ. вищ. навч. закл. / О.В. Зазимко, М.С. Корольчук, В.М. Корольчук та ін. Київ : Київ. нац. торг.-екон. ун-т, 2016. 384 с.

21. Holland, J.L. Making vocational choices: A theory of vocational personalities and work environments. Englewood Cliffs, NJ: Prentice Hall, 1985.

\section{REFERENCES}

1. Zakon Ukrainy "Pro zainiatist naselennia» [Elektronnyi resurs]. [Law of Ukraine «On employment of population»]. URL: https://zakon.rada.gov.ua/laws/show/5067-17\#Text [in Ukrainian] 
2. Zakon Ukrainy «Pro reklamu» [Elektronnyi resurs]. [Law of Ukraine «On Advertising»]. URL: https:// zakon.rada.gov.ua/laws/show/270/96-вp\#Text [in Ukrainian]

3. Adler A. (1997) Nauka zhyt ; per. s anhl. [The science of living; transl. from English]. Kyiv: Port-Royal. [in Russian]

4. Bauer M. (2014) Kurs na liderstvo: Al'ternativa ierarhicheskoj sisteme upravleniya kompaniej ; per s angl. [Leadership Course: An Alternative to the Hierarchical Company Management System; transl. from English]. Moscow: Al'pina Pablisher. [in Russian]

5. Bern E. (2010) Igry, v kotorye igrayut lyudi. Lyudi, kotorye igrayut v igry ; per. s angl. [Games that is played by people. People that play games; transl. from English]. Moscow: Eksmo. [in Russian]

6. Bondarchuk O. I. (2016) Model osobystisnoho zrostannia maibutnikh fakhivtsiv // Tezy I Vseukrainskoi naukovo-praktychnoi internet-konferentsii (z mizhnarodnoiu uchastiu) «Osobystisne zrostannia: teoriia i praktyka» (m. Zhytomyr, 22 kvitnia 2016 r.) [A model of personality increase of future specialists // Of Thesis And Allukrainian research and practice internet-conference (with international participation) is the «Personality increase: theory and practice» (Zhytomyr, 2016, April, 22)]. Zhytomyr. [in Ukrainian]

7. Bondarchuk O. I., Nezhynska O. O. (2017) Liderstvo u diialnosti kerivnyka osvitnoi orhanizatsii : spetskurs dlia slukhachiv ochno-dystantsiinoi formy navchannia v systemi pisliadyplomnoi pedahohichnoi osvity; NAPN Ukrainy, Un-t menedzh. osvity [Leadership in activity of leader of educational organization: the special course for the listeners of the internal from distance form of studies in the system of postgraduate pedagogical education; NAPS of Ukraine, University of Educational Management]. Kyiv. [in Ukrainian]

8. Bulakh T. D. (2010) Spetsyfika televiziinoi reklamy [Tekst] // Visnyk Kharkivskoi derzhavnoi akademii kultury [Specific of televisional advertisement [Text] // Announcer of the Kharkiv state academy of culture]. Kharkiv. [in Ukrainian]

9. Dosenko A. K. Sotsialna reklama i mekhanizmy vplyvu na tsilovu audytoriiu [Elektronnyi resurs]. [A social advertisement and mechanisms of influence are on a target audience]. URL: http://www.kymu.edu.ua/wsc/ toms/09/112-114.pdf [in Ukrainian]

10. Kuznecov P. A. (2010) Social'naya reklama: teoriya i praktika: ucheb. posobie dlya studentov vuzov [Social advertisement: theory and practice: a study guide for the students of institutions of higher learning]. Moscow: YUNITI-Dana. [in Russian]

11. Maslou A. (2003) Motivaciya i lichnost'. 3-e izd. [Motivation and personality. 3th publ]. St. Petersburg and others: Peter. [in Russian]

12. Nezhynska O. O. (2014) Vplyv hendernykh stereotypiv batkiv na osobystisnyi rozvytok pidlitka // Aktualni problemy psykholohii: zb. nauk. prats Instytutu psykholohii im. H. S. Kostiuka NAPN Ukrainy [Influence of gender stereotypes of parents on personality development of teenager // Actual problems of psychology: zb. sciences. pr. of the Institute of Psychology im. G. S. Kostyuk NAPS of Ukraine]. Kyiv. [in Ukrainian]

13. Nezhynska O. O. (2014) Henderna tolerantnist yak chynnyk osobystisnoho rozvytku pidlitkiv // Visnyk pisliadyplomnoi osvity: zb. nauk. prats Un-tu menedzh. osvity NAPN Ukrainy [Gender tolerance as factor of personality development of teenagers // Announcer of postgraduate education : zb. sciences. pr. of University of Educational Management NAPS of Ukraine]. Kyiv: ATOPOL. [in Ukrainian]

14. Nezhynska O. O., Zorina V. I. (2014) Psykholohichna pidhotovka pedahohichnykh pratsivnykiv do rozvytku moralno-tsinnisnykh uiavlen pidlitkiv : spetskurs dlia slukhachiv ochno-dystants. formy navchannia $v$ systemi pisliadyplom. ped. osvity; NAPN Ukrainy, Un-t menedzh. osvity [Psychological preparation of pedagogical workers to development of the morally-valued presentations of teenagers: the special course for the listeners of the internal from distance form of studies in the system of postgraduate pedagogical education; NAPS of Ukraine, University of Educational Management]. Kyiv. [in Ukrainian]

15. Nezhynska O. O., Tymenko V. M. (2017) Kouchynh yak tekhnolohiia rozvytku liderstva u sferi osvity // Teoretychnyi ta naukovo-metodychnyi chasopys «Vyshcha osvita Ukrainy»; 2017, № 2 (dodatok 1) ; Tematychnyi vypusk «Universytet i liderstvo» [Coaching as a technology of development of leadership in the field of education // The Theoretical and scientifically-methodical magazine «Higher education of Ukraine»; 2017, № 2 (addition 1); The thematic producing is «University and leadership»]. Kyiv: Institute of higher education NAPS of Ukraine. [in Ukrainian]

16. Ouen H., Hodzhson V., Gazzard N. (2005) Prizvanie - lider: Polnoe rukovodstvo po effektivnomu liderstvu [Calling is a leader: Complete guidance on effective leadership.]. Dnipropetrovsk: Balans Biznes Buks. [in Russian]

17. Pidhotovka kerivnykiv zakladiv osvity do proforiientatsiinoi roboty z uchnivskoiu ta studentskoiu moloddiu: spetskurs dlia slukhachiv ochno-dystants. formy navchannia v systemi pisliadyplom. ped. osvity / O. I. Bondarchuk, A. S. Moskalova, O. O. Nezhynska, O. A. Prokopenko (2012) [Preparation of leaders of establishments of education to профорієнтаційної work with student's and student young people: the 
special course for the listeners of the internal from distance form of studies in the system of postgraduate pedagogical education; NAPS of Ukraine, University of Educational Management]. Kyiv. [in Ukrainian]

18. Pryazhnikova E. YU., Pryazhnikov N. S. (2005) Proforientaciya: ucheb. posobie dlya stud. vyssh. ucheb. zavedenij [Vocational orientation: a study guide for the students of institutions of higher learning]. Moscow: Academy. [in Russian]

19. Psikhologiya professional nogo samoopredeleniya : uchebnoe posobie / E.A. Klimov (1996) Rostov-naDonu: Feniks. [in Russian]

20. Psykholohiia reklamy: navchalnyi posibnyk dlia stud. vyshch. navch. zakl. / O. V. Zazymko, M. S. Korolchuk, V. M. Korolchuk ta in. (2016) [Psychology of advertisement: a study guide for the students of institutions of higher learning]. Kyiv: Kyiv. national trade and economic university. [in Ukrainian]

21. Holland J. L. (1985) Making vocational choices: A theory of vocational personalities and work environments. Englewood Cliffs, NJ: Prentice Hall. 